\title{
Community Satisfaction of the Urban Flood Control System Improvement Project (UFCSI)
}

\author{
Mohammad Sofyan \\ Institute of Social Sciences and Management STIAMI \\ Correspondent:sofyan.proyek@gmail.com
}

Submitted: 6 August 2019. Revised: 25 August, 18 Sept 2019. Published: 30 October 2019.

\begin{abstract}
The purpose of this study is to encourage ownership, responsibility and to develop stakeholders and policy makers for the river normalization program in the pre-construction, construction and post-construction stages. The use of the IPA method to measure community satisfaction in the quadrants on the Importance Performance Matrix map. The results of the study showed that the socialization from the Department of Water and Public Works, when the project was finished, was not in line with community expectations. Flood control projects that have been built, coordination with the contractor at the time of project implementation, socialization from the city government prior to project implementation, socialization from the city government when the project is finished, socialization from the river hall at the time before project implementation, socialization from the river hall at the time the project was completed, dissemination of information from the irrigation service prior to project implementation, and community involvement in project implementation. The process of land clearing, and the price agreement that has been reached. Improved land clearing, and price agreements that have been reached can be reconsidered because their impact on the benefits felt by the community is very small.

Keywords: Importance Performance Analysis, Community Satisfaction, Urban Flood Control
\end{abstract}

\section{INTRODUCTION}

Tidal flooding is an event caused by rising sea levels globally. The existence of ups and downs and tides will affect the inundation conditions that occur.This phenomenon presents the occurrence of floods caused by rising sea levels called tidal floods. The area of tidal inundation when sea water experiences the highest tide will increase and extend to the land in accordance with land surface elevation or coastal land morphology.

Disaster management is the science that studies disasters and all aspects related to disasters, especially disaster risk and how to avoid disaster risk. Disaster management is a dynamic process of how the management functions that we know so far for example planning function, organizing, actuating, and controlling functions (Nurjanah, Sugiharto, K, B.P, \& Adikoesoemo, 2011). Natural disaster management (disaster management) needs to be carried out through stages: (1) preparation; (2) deterrence / handling (facing disaster); (3) repairs due to damage (reconstruction); (4) re-functioning of damaged social infrastructure and facilities (rehabilitation); and (5) taming natural movements that cause disasters (mitigation) (Carter, 2008).

Flood disaster is a disaster that occurs because it is caused by high rainfall, where the watershed cannot accommodate large water discharges and eventually overflow the land. Siltation and narrowing of the river are the factors. Not only that, the existence of illegal logging which causes deforestation to be a very big influence, this makes the infiltration area not optimal so that 29 | Ilomata International Journal of Social Science

Vol. 1 No. 1 October 2019 
Sofyan

flood disaster cannot be avoided. Flood disaster management requires good disaster management because this can minimize the impact (Suleman \& Apsari, 2017).

In a more technical interest, flooding can be referred to as a pool of water that occurs in a location caused by: (1) land use change in a Watershed; (2) garbage disposal; (3) erosion and sedimentation; (4) slums along the drainage path; (5) improper flood control system planning; (6) high rainfall; (7) the physiographic / geophysical influence of the river; (8) inadequate river and drainage capacity; (9) the influence of the tide; (10) land subsidence and rob (inundation due to tides); (11) land drainage; (12) weirs and water structures; and (13) damage to flood control buildings (Kodoatie \& Sugiyanto, 2002).

Social impact analysis is a process that ensures that the implementation of an action is sufficiently informed and considers key social issues that are relevant, as well as provides a participatory strategy to engage stakeholders broadly. Therefore, various variables that potentially affect the impact and success of a program and policy include: socioeconomic status, age, gender, language, and others. Must be clearly known. The implication is that, through data collection and analysis, social impacts make planners able to consult with other stakeholders about the priority of critical issues and determine how these are addressed, then the social impact of the urban flood management project is interpreted freely is an activity carried out to find out social problems and potential participation that is predicted to emerge in the pre-construction, construction, and postconstruction stages as consideration in developing an urban flood impact management program seen from multistakesholder perspective (Sofyan, 2016).

The role of stakeholders in flood disaster management, which in this case is carried out by the central government, local governments, BNPB and private and international institutions have been regulated in government regulations. Agencies / institutions have their respective duties, functions and roles in accordance with the regulations that have been set. However, it can be seen from the duties, functions and roles, that the BNPB / BPBD has a directly authorized role in disaster management, particularly in flood mitigation. This is based on the establishment of the BNPB / $\mathrm{BPBD}$ institution as a center in national and regional disaster management (Suleman \& Apsari, 2017).

Public satisfaction is a major factor that must be considered by public service providers, because public satisfaction will determine the success of the government in carrying out public services. The definition of community satisfaction is often equated with the definition of customer satisfaction or customer satisfaction, this is only distinguished by who the provider is and what motives the service is provided. Service providers in public services are employees of government agencies that carry out public service tasks in accordance with mandated laws and regulations and recipients of public services are people, communities, government agency agencies and the business world, who benefit from an activity of public service delivery ( Rezha, Rochmah, \& Siswidiyanto, 2009).

The results of other studies show that the people of Bedono Village as a coastal community carry out various adaptation strategies in dealing with the tidal flood. Adaptation strategies are carried out through (1) physical adaptation strategies, (2) economic adaptation strategies, and (3) social adaptation strategies. The tidal flood disaster has implications for the resilience of the Bedono Village area. The tidal flood has implications for geographical, demographic, natural resources, economic, social and cultural resources. Gatra ideology, politics and security are not implicated by the tidal flood disaster (Asrofi, Hardoyo, \& Sri Hadmoko, 2017). 
Sofyan

The policy regarding handling illegal settlements in Pesanggrahan River is the responsibility of all stakeholders involved in handling and participating in the existence of illegal settlements which is manifested in the actions and participation in handling squatters in Kampung Baru and the existence and resettlement of illegal settlements on the banks of the Kali Pesanggrahan, Kampung Baru is influenced by factors including the complete facilities and infrastructure, the recognition of the legality of citizens by providing ID cards, less strict law enforcement, close to work locations and centers of economic activity. Based on this conclusion the author recommends the West Jakarta Regional Government to review policies regarding the protection of watersheds and provide socialization to the community and improve coordination with related agencies (Sasanto et al., 2010).

\section{METHOD}

The research method used in this study is descriptive research. Descriptive research aims to describe precisely the characteristics of an individual, a particular condition, symptom or group, or to determine the frequency or spread of a symptom or the frequency of a certain relationship between a state / symptom with other conditions / symptoms in society. This research is used to answer questions about what or how things are (phenomena, events) and report as is. In order to describe the phenomenon, intensive field observation is needed for the phenomenon under study. This research was conducted on the people of Batang Anai District, Padang City, Koto Tangah District, Padang Pariaman District, Kemuning District, Palembang City, Gorontalo City South District, Sukolilo and Rungkut District in Sidoarjo City, Pra Pvt Kulon Mojokerto City, and Sooko District Mojokerto Regency. The people who were respondents in the community satisfaction survey were 500 respondents, but those who returned the questionnaire and filled in completely were 421 respondents.

Importance Performance Analysis (IPA) allows a simultaneous comparison of the quality of performance appraisals with the importance ratings given by the community for various measured quality items. In the Natural Sciences, community perceptions and important values are plotted on a grid divided into 4 quadrants, formed based on the average rating of perceived importance. These values are then assessed according to their position in the quadrant (Bindu \& Kanagaraj, 2013).

IPA has been generally accepted and used in various fields of study because of its ease of application and display of analysis results that facilitate the proposed improvement of performance. The application of IPA techniques begins with the identification of attributes that are relevant to the observed choice situation. The list of attributes can be developed by referring to the literature, conducting interviews, and using managerial assessments using mean, median or ranking measurements, importance scores and performance attributes are collected and classified into high or low categories; then by pairing the two sets of ranking, each attribute is placed into one of the four quadrants of performance interest (Crompton \& Duray, 1985).

Table 1. Number of Distribute and Return Questionnaires to the Community in Each Sub-Project

\begin{tabular}{lrrr}
\hline \multicolumn{1}{c}{ Name Sub-Project } & \multicolumn{3}{c}{ distribute questionnaires } \\
& Distribute & Return & \multicolumn{1}{c}{$\%$} \\
\hline Padang City (P-1) & 100 & 99 & 99,0 \\
\hline Palembang City (P-2) & 100 & 82 & 82,0 \\
\hline Surabaya-Wonokromo (P-3) & 100 & 46 & 46,0 \\
\hline
\end{tabular}




\begin{tabular}{lrrr}
\hline \multicolumn{1}{c}{ Name Sub-Project } & \multicolumn{3}{c}{ distribute questionnaires } \\
& Distribute & Return & \multicolumn{1}{c}{$\%$} \\
\hline Surabaya-Brangkal (P-4) & 100 & 100 & 100,0 \\
\hline Gorontalo (P-5) & 100 & 94 & 94,0 \\
\hline Total & 500 & 421 & 84,2
\end{tabular}

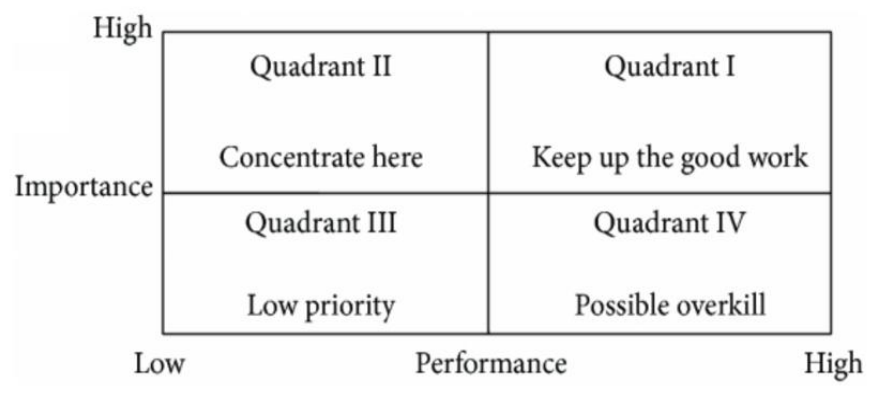

figure 1. Map Importance-Performance

Quadrant 1 (Keep Up The Good Work). Areas that contain factors that are considered important by the community, and factors that are considered stakeholders are in accordance with what they feel so that the level of satisfaction is relatively higher. The variables included in this quadrant must be retained.

Quadrant 2 (Concentrate Here). Areas that contain factors that are considered important by the community, but in fact these factors are not in line with stakeholder expectations (the level of satisfaction obtained is still low). The variables included in this quadrant must be increased.

Quadrant 3 (Low Priority). Areas that contain factors that are considered less important by the community, and in fact their performance is not too special. The increase in variables included in this quadrant can be reconsidered because the effect on the benefits felt by stakeholders is very small.

Quadrant 4 (Possible Overkill). Areas that contain factors that are considered less important by stakeholders, and are considered too excessive. The variables included in this quadrant need attention to be maintained effectively and efficiently.

\section{RESULT AND DISCUSSION}

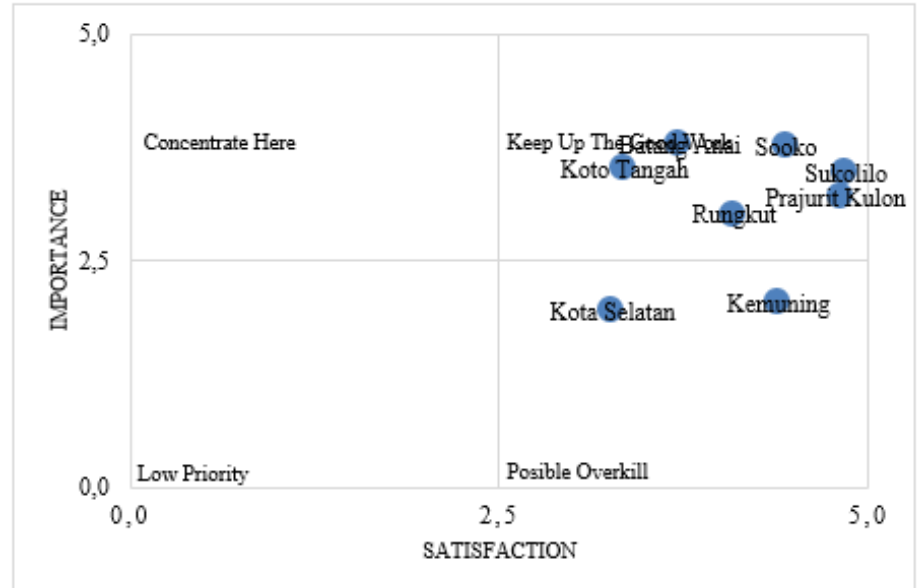

Figure 2. Flood control projects that have been built 
Sofyan

Flood control projects that have been built, coordination with the contractor during project implementation, socialization from the City Government prior to the project implementation, socialization from the City Government when project implementation completed, socialization from the River Hall Party prior to the project implementation, socialization from the River Hall Party after completion project implementation, socialization from irrigation public works department before project implementation, socialization from irrigation public works department when project implementation completed, community involvement in project implementation, land and house acquisition processes, and price agreements that have been reached according to the people of Batang Anai, Koto Tangah, Kulon, Rungkut, Sooko, and Sukolilo Districts are in the Quadrant 1 (Keep Up The Good Work). These factors are considered important by the community, and the factors considered by the community are in accordance with what they feel so that the level of satisfaction is relatively higher and must be maintained. Meanwhile, according to the people of Kemuning and Kota Selatan are in Quadrant 4 (possible Overkill). Factors that are considered less important by the community, and are felt to be too excessive. Improvement of flood control projects that have been built, Coordination with Contractors during project implementation, socialization from the City Government prior to the project implementation, socialization from the City Government after the project implementation, Socialization from the River Hall Parties before the project implementation, Socialization from Balai Sungai when project implementation completed, socialization from irrigation public works department before project implementation, socialization from irrigation public works department when project implementation completed, community involvement in project implementation, land and house acquisition process, and price agreements that have been reached can be reconsidered because of their influence the benefits felt by the people of Kemuning District and South City are very small.

Community involvement in the current era of development absolutely must be done because they are the real parties who will enjoy the results of development and furthermore that they are the ones who actually know the condition of the region. Community involvement must be started from the moment the idea arises for the development of flood management and be directly involved to the operation and maintenance of flood control buildings. This community involvement has a mission in addition to increasing the role and sense of responsibility of the community as well in order to improve the ability of human resources in their environment.

\section{CONCLUSION}

Urban flood control projects have not been effective in overcoming flood problems in Batang Anai District, Padang City, Koto Tangah District, Padang Pariaman District, Kemuning District Palembang City, Kota Selatan District Gorontalo City, Sukolilo and Rungkut Districts in Sidoarjo City, Pra Soldiers Subdistrict, Mojokerto City, and Sooko District, Mojokerto Regency. There has been no effective socialization from the City / Regency Government, BBWS / BWS, and the Department of Water Resources when completing the implementation of the urban flood control project, especially in terms of inviting the public to maintain and maintain the flood control project that has been completed.

Further evaluation of urban flood control projects is needed from the selection of project locations, project management, and project design, so that in the future flood control projects are able to control and manage floods properly. Socialization from the Brantas River Hall, the City 
Community Satisfaction of the Urban Flood Control System Improvement Project (UFCSI)

Sofyan

Government and the Water Resources Office at the time of the completion of the urban flood control project is needed.

\section{REFERENCE}

Asrofi, A., Hardoyo, S. R., \& Sri Hadmoko, D. (2017). Strategi Adaptasi Masyarakat Pesisir Dalam Penanganan Bencana Banjir Rob Dan Implikasinya Terhadap Ketahanan Wilayah (Studi Di Desa Bedono Kecamatan Sayung Kabupaten Demak Jawa Tengah). Jurnal Ketahanan Nasional, 23(2), 125-144. https://doi.org/10.22146/jkn.26257

Bindu, T., \& Kanagaraj, D. C. (2013). Importance - Performance Analysis as a Strategic Tool for Destination Attractiveness : an Analysis of Domestic Travelers To Kerala. International Journal of Management \& Business Studies, 3(1), 61-67. https://doi.org/2230-9519

Carter, W. N. (2008). Disaster Management A Disaster Manager's Handbook. In Asian Development Bank.

Crompton, J. L., \& Duray, N. A. (1985). An investigation of the relative efficacy of four alternative approaches to importance-performance analysis. Journal of the Academy of Marketing Science. https://doi.org/10.1007/BF02737200

Kodoatie, R. J., \& Sugiyanto. (2002). Banjir, Beberapa Penyebab dan Pengendaliannya dalam Perspektif Lingkungan. Pustaka Pelajar. https://doi.org/10.1016/j.npg.2013.07.003

Nurjanah, Sugiharto, R., K, D., B.P, S., \& Adikoesoemo. (2011). Manajemen Bencana. In Alfabeta. Rezha, F., Rochmah, S., \& Siswidiyanto. (2009). Analisis Pengaruh Kualitas Pelayanan Publik Terhadap Kepuasan Masyarakat (Studi tentang Pelayanan Perekaman Kartu Tanda Penduduk Elektronik (e-KTP) di Kota Depok). Jurnal Administrasi Publik, 1(5), 981-990. Retrieved from http://administrasipublik.studentjournal.ub.ac.id/index.php/jap/article/view/116/129

Sasanto, R., Khair, A. S., Kunci, K., Kebijakan, :, Squatters, P., Kembali, B., \& Ilegal, K. (2010). Analisis Kebijakan Pemerintah Dalam Penanganan Permukiman Ilegal Di Bantaran Sungai Studi Kasus: Bantaran Kali Pesanggrahan Kampung Baru, Kedoya Utara, Kebon Jeruk. Jurnal Planesa, 1(2), 146-152. Retrieved from https:// ejurnal.esaunggul.ac.id/index.php/planesa/article/view/525/487

Sofyan, M. (2016). Analisa Kepuasan Masyarakat Kota Dan Kabupaten Mojokerto Terhadap Proyek Pengendalian Banjir Perkotaan Dengan Metode Importance Performance Analysis. 13(2), 320-329. Retrieved from https://jurnal.ibmt.ac.id/index.php/jeksekutif/article/view/121/pdf

Suleman, S. A., \& Apsari, N. C. (2017). Peran Stakeholder Dalam Manajemen Bencana Banjir. Prosiding Penelitian Dan Pengabdian Kepada Masyarakat, 53-59. https://doi.org/10.24198/jppm.v4i1.14210 